\title{
НАКАНУНЕ ВНЕОЧЕРЕДНЫХ ВЫБОРОВ В ПАРЛАМЕНТ АВСТРИИ: ПОДОПЛЁКА СОБЫТИЙ
}

\begin{abstract}
Аннотация. В конце сентября 2019 г. в Австрии состоятся парламентские выборы. Они имеют статус внеочередных, и в том для дунайско-альпийского государства нет ничего особенного. Здесь это происходит практически через раз. Особенностью нынешнего внеочередного волеизъявления австрийцев является его причина. А ею стал острый конфликт между коалиционными партнёрами - консервативной Австрийской народной партией (АНП) и националистической Австрийской партией Свободы (АПС). В эпицентре ссоры коалиционеров оказалась статья в немеиком журнале «Шпигель», опубликованная в середине мая 2019 г.
\end{abstract}

Ключевые слова: Австрия, выборы, парламент, Народная партия, Партия свободы.

\section{«Шпигельгейт»}

Из опубликованной в середине мая 2019 г. в журнале «Шпигель» статьи следовало, что в конце августа 2017 г., в канун очередных парламентских выборов, лидеры АПС Х.-К. Штрахе и Й. Гуденус обсуждали с русскоговорящей предпринимательницей из Латвии планы нелегального финансирования избирательной кампании АПС. Взамен они обещали содействовать бизнес-планам незнакомки, в частности, переходу под её контроль значительной части крупнейшей в Австрии строительной фирмы «Страбаг».

Из публикации в «Шпигеле» выяснилось, что имела место заурядная политическая провокация с целью компрометации АПС. Организаторы этой «встречи», журналисты, явно не симпатизировавшие националистам, тайно произвели аудио- и видеозапись бесед на щекотливые темы австрийской политики. Выяснилось, что «дамой из Латвии» была специально подготовленная гражданка Боснии. Всё, предлагавшееся ею, - очевидный «фэйк», но это вполне вписывалось в предвыборную тактику ничем не брезговавших «свободников» ${ }^{1}$.

Очевидно, что лихие журналисты планировали опубликовать свой компромат в канун тех парламентских выборов, однако не нашли солидного покупателя этого материала. Но всё получилось почти по Чехову. Висящее на стене в первом акте ружье должно, в конце концов, выстрелить. И выстрел прозвучал в канун другого волеизъявления - выборов в Европейский парламент, состоявшихся в Австрии в конце мая 2019 г. Однако расчёты авторов публикации на то, что она нанесёт серьёзный электоральный урон АПС, не оправдались. С учётом значительного числа австрийцев, пришедших к урнам для голосования (около 60\%), электорат АПС, по сравнению с последними (2014 г.) выборами в Европарламент, численно даже увеличился.

И всё же информационный выстрел, прозвучавший в середине мая, никак нельзя на-

(C) Швейцер Владимир Яковлевич - доктор исторических наук, главный научный сотрудник, руководитель Отдела социальных и политических исследований Института Европы РАН. Адрес: 125009, Россия, Москва, ул. Моховая, д.11, стр.3. E-mail: partsist@list.ru.

DOI: http://dx.doi.org/10.15211/vestnikieran420191114

${ }^{1}$ Der Spiegel 2019, 18 Mai, №21. S.78-83. 
звать холостым. Канцлер Австрии С. Курц потребовал у руководства «свободников» объяснений и оценки случившегося в августе 2017 г. Его отнюдь не удовлетворила отставка Х.-К. Штрахе с поста вице-канцлера, а его подельника с места председателя парламентской фракции АПС. Однако руководство коалиционного партнёра никак не осудило политические про-жекты соратников. Резкими оценками были удостоены непорядочные журналисты, подставившие Штрахе и Гуденуса. Возмущённый канцлер разорвал коалиционное соглашение с АПС, а президент страны А. ван дер Беллен предложил ему вплоть до новых выборов остать-ся на своём посту. Но усилиями АПС и других парламентских партий Курцу был объявлен вотум недоверия. Случай в послевоенной истории Австрии беспрецедентный. Не имело в прошлом аналога и решение президента А. ван дер Беллена передать власть временному непартийному кабинету министров во главе с председателем Верховного суда Австрии ${ }^{1}$.

\section{Заокеанские мотивы в венском вальсе}

На наш взгляд, объектом крупного политического скандала был не только и не столько Х.-К. Штрахе. Скорее всего, кому-то очень не нравилась фигура канцлера С. Курца, провозгласившего с приходом во власть политику активного австрийского нейтралитета. Отметим, что партнёр по коалиции - евроскептическая АПС - была элегантно отодвинута от участия в решении европейских и международных проблем. Основные вопросы внешней политики кан-цлер взял в собственные руки. Министром иностранных дел стала К. Кнайсель - беспартийный эксперт по ближневосточным делам. Влиятельное место советника по взаимоотношениям с Россией получила М. Лефлер-Клестиль, долгие годы работавшая в австрийском посольстве в Москве.

Провозгласив в качестве одной из своих внешнеполитических задач посредничество в конфликте Запада и Востока, канцлер Курц повысил свой удельный политический вес в европейской политике. Обкатка темы посредничества была им сделана в 2017 г. в качестве ротационного председателя ОБСЕ. В частности, в сентябре того же года он впервые выдвинул идею проведения в Вене российско-американского саммита. О желании австрийцев принять В.В. Путина и Д. Трампа Курц неоднократно говорил и заняв пост канцлера. Но появление та-кого посредника явно не устраивало американцев. Они не забыли, что третьей столицей Европы, резко критиковавшей Трампа за внесённый им дисбаланс в международную политику, была, после Берлина и Парижа, именно Вена. Для Курца и других ведущих европейских политиков антиевропеизм президента США был неприемлем также и тем ущербом экономическим интересам Австрии, который был очевиден и в торпедировании проекта «Северный поток-2», и в резком повышении пошлин на австрийский экспорт в США изделий алюминиевой и сталелитейной промышленности. Да и в целом американская политика «закручивания гаек», будь то темы Дальнего или Ближнего Востока, встречала вполне естественную отповедь у С. Курца, созвучную критике таких лидеров ЕС, как А. Меркель и Э. Макрон.

Сам формат посредничества был для Трампа неприемлем. Он, как опытный бизнес-игрок, предпочитал добиваться желаемого результата в очных контактах. Тем более ему не нужен был в этом качестве лидер маленькой европейской страны, по возрасту более чем вдвое моложе президента США. Первым аккордом в антиавстрийской симфонии стал отказ Трампа от Вены как возможного места встречи с президентом России. Между тем именно этот сюжет мог стать важным элементом визита Путина в Вену в начале июня 2018 г. и его

\footnotetext{
${ }^{1}$ Der Spiegel 2019, 1 Juni, №28. S. 87.
}

Научно-аналитический вестник ИЕ РАН, 2019, №4 
бесед с австрийской политической элитой. Тем более что уже дважды - в 1961 и 1979 гг. лидеры СССР и США общались именно в столице Австрии. В конечном итоге встреча президентов России и США состоялась в Хельсинки - финское руководство не было замечено в хоре резких критиков хозяина Белого дома.

Тема австрийского посредничества возникла и после того, как было объявлено о планировавшемся в Берлине саммите лидеров России и Германии. С учётом ставших известными А. Меркель фактов прослушки спецслужбами США её телефонных бесед и хакерских атак на её аккаунты, она приватным образом попросила К. Кнайсель во время присутствия президента России в середине августа 2018 г. на свадьбе главы австрийского МИДа проинформиро-вать его о своей позиции по ряду международных проблем. Тем более что со свадьбы президент России прямым ходом отправился в Берлин на заранее запланированную встречу с А. Меркель.

Посредничество Кнайсель явно не понравилось американской стороне. Вряд ли чистым совпадением стало то, что уже в ноябре того же года Государственный департамент обратил внимание посольства США в Вене на усиление противодействия российскому влиянию в Австрии. В этой связи сложно назвать чистой случайностью информационный вброс по теме «русского шпионажа» на территории нейтрального государства.

\section{Настоящий полковник}

Из сообщений прессы, появившихся в ноябре 2018 г., следовало, что не названный отставной австрийский полковник был якобы ещё в 80-е гг. прошлого века завербован спецслужбами СССР и вплоть до 2018 г. продолжал сотрудничать с российским ГРУ. Полковник был арестован, но никаких уточняющих обстоятельств общественности не сообщили.

Тем не менее акцент очевиден - русские всегда вели в Австрии подрывную деятельность. Возникла довольно щекотливая ситуация, которую попытались разрулить на совместной пресс-конференции Курц и Кнайсель. Первый резонно заявил, что «шпионаж недопустим», а глава австрийского МИДа даже отложила свой визит в Россию. Но оба политика не привели фактов, доказывавших антиавстрийские действия «настоящего полковника». Полковничья тема продолжилась в июле 2019 г. Был назван московский куратор встреч, некто И.Е. Зайцев.

Очевидно, что новый информационный вброс должен был, фигурально говоря, убить одним выстрелом сразу двух зайцев. Общественность ориентировалась на «русский след», а тень падала на С. Курца, который не сообщил стране об известных ему обстоятельствах «дела полковника Н.». С учётом набиравшей обороты предвыборной борьбы всё это никак не ло-жилось в информационный позитив экс-канцлера.

Что касается «русских сезонов 2019» в Вене, то к ним можно отнести и уже упоминавшуюся майскую публикацию в «Шпигеле», кстати, день в день совпавшую с визитом в Сочи президента А. ван дер Беллена и К. Кнайсель. Результаты переговоров на высшем уровне свидетельствовали о наличии у обеих сторон сходных точек зрения по ряду международных проблем и о желании развивать двусторонние отношения в различных областях.

Упомянутый нформационный вброс июля 2019 г. интересен тем, что сделана попытка нанести укол и А. Меркель. Ведь о Зайцеве сообщила Австрии, согласно прессе, соответствующая спецслужба ФРГ. А канцлерин должна, по идее, контролировать Ведомство по охране Конституции. Следовательно, Меркель не смогла вовремя предупредить 
своих венских коллег. И здесь американский интерес налицо, ибо был нанесён информационный удар сразу по двум критикующим Д. Трампа популярным европейским политикам.

Очевидно, что в данном случае, как, впрочем, и во многих других эпизодах современных международных отношений, политика и конспирология идут параллельным курсом. Информационный контент оказывает определённое влияние на умонастроения европейцев, подчас способствуя принятию ими решений, далеко не всегда отвечающих коренным интересам собственных государств. Насколько этот вывод обоснован, будет, в частности, подтверждено или опровергнуто на предстоящих сентябрьских выборах в Австрии.

Сложность спонтанно возникшего кризиса власти отягощена тем, что назначенные на конец сентября 2019 г. внеочередные парламентские выборы вряд ли выведут страну из очевидного политического тупика. С учётом результатов выборов в Европарламент трудно предположить кардинальные перемены в электоральной ситуации. Лидерство АНП и, соответственно, экс-канцлера С. Курца очевидно. Однако этот политик вряд ли сможет в обозримый после выборов период сформировать новый коалиционный кабинет. Со второй партией страны - СДПА - у него принципиальные расхождения по целому комплексу социально-эко-номических проблем. Возобновлять коалицию с АПС, в которой у власти остались ближайшие сподвижники X-К. Штрахе, он явно не захочет. Небольшие в электоральном отношении партии либералов и экологистов вряд ли станут в парламенте устойчивым довеском для АНП.

Трудно предположить, что в оставшееся до выборов время будет найден консенсус по вопросам экономики, социальной политики, экологии, теме иммиграции. Не менее очевиден и отрицательный ответ на вопрос о перспективах австрийской политической модели. Во всяком случае, те варианты коалиций, которые справлялись в прошлом с задачами внешней и внутренней политики, в новых условиях себя уже исчерпали. В целом австрийский казус 2019 г. оказывается в ряду других, заранее не просчитанных европейскими политиками ситуаций, порожденных явными нестыковками национальных, общеконтинентальных и глобальных проблем.

\section{On the eve of extraordinary election in the parliament of Austria: a background of the events}

Author. Vladimir Schweizer, Doctor of Sciences (History), Head of the Department of Social and Political Studies, Institute of Europe, Russian Academy of Sciences. Address: 11-3, Mokhovaya str., Moscow, Russia, 125009. E-mail: partsist@list.ru.

Abstract. The next parliamentary election in Austria is to be held on late September, 2019. This election is an extraordinary one, and that is a normal situation for this country. Austria often holds such extraordinary elections. The specific characteristics of the upcoming election is its reason, namely a sharp conflict between coalition partners - conservative Austrian People's Party, and nationalist Austrian Party for Freedom. The cause of the conflict is the article in «Spigel» journal, earlier this year, in May's issue.

Key words: Austria, election, parliament, Austrian People's Party, Austrian Party for Freedom.

DOI: http://dx.doi.org/10.15211/vestnikieran420191114 